\title{
Trichomycterus anhanga, a new species of miniature catfish related to T. hasemani and T. johnsoni (Siluriformes: Trichomycteridae) from the Amazon basin, Brazil
}

\author{
Guilherme M. Dutra ${ }^{1}$, Wolmar B. Wosiacki ${ }^{1}$ and Mario C. C. de Pinna²
}

Trichomycterus anhanga is described from the Amazon basin, northern Brazil. The species is diagnosed by the latero-sensory system which is restricted to LL1 and LL2, the pectoral fin with two branched rays, the absence of pelvic fins and girdle, the reduced jaws and pharyngeal dentition, the presence of six to seven interopercular odontodes, the absence of a lateral series of spots, the presence of a small dark spot on the ventral surface of the mandibular symphysis, the narrow comma-shaped palatine, the absence of procurrent rays anterior to the dorsal and anal fins, the position of insertion of the first dorsal-fin pterygiophore and the presence of a single pair of pleural ribs. Trichomycterus anhanga shares with $T$. hasemani and $T$. johnsoni a wide cranial fontanel which occupies most of the skull roof. Miniaturization as well as synapomorphies for the $T$. hasemani group are discussed.

Trichomycterus anhanga é descrita da bacia Amazônica, norte do Brasil. A espécie é diagnosticada pelo sistema láterosensorial restrito à LL1 e LL2, nadadeira peitoral com dois raios ramificados, ausência de nadadeiras e cintura pélvica, redução da dentição das maxilas e faringiana, presença de seis ou sete odontódeos no interopérculo, ausência de série lateral de manchas, presença de uma pequena mancha escura na superfície ventral da sínfise mandibular, palatino estreito, em forma de vírgula, ausência de raios vestigiais anteriores às nadadeiras dorsal e anal, inserção do primeiro pterigióforo da nadadeira dorsal e presença de um único par de costelas pleurais. Trichomycterus anhanga compartilha com T. hasemani e T. johnsoni a presença de fontanela craniana ampla, ocupando a maior parte do teto do crânio. A miniaturização e caracteres sinapomórficos para o grupo T. hasemani são discutidos.

Key words: Taxonomy, Trichomycterinae, Trichomycterus hasemani group.

\section{Introduction}

The Trichomycteridae is a large family of catfishes, widely distributed throughout most of cis- and trans-Andean South America, Panama and Costa Rica (de Pinna \& Wosiacki, 2003). It is currently subdivided into eight subfamilies, of which Trichomycterinae is the only one which is not demonstrably monophyletic (Baskin, 1973; de Pinna, 1989, 1998; Wosiacki, 2002). Arratia (1990) and more recently Datovo \& Bockmann (2010) proposed some putatively derived morphological characters for Trichomycterinae. However, those studies included neither Trichomycterus hasemani (Eigenmann) or $T$. johnsoni (Fowler), which form a monophyletic clade (Wosiacki, 2002) of markedly distinctive miniature species that is related to non-trichomycterine taxa (de Pinna, 1989, 1998). The group composed of T. hasemani plus T. johnsoni is herein called "T. hasemani group".
These catfish live interstitially on the sandy bottom and amongst the leaf litter and debris of riverbeds (Wosiacki, 2002). Recently, field work focusing on unusual microhabitats like leaf litter and sand banks has resulted in an increase in the number of records of miniature species (Sousa \& Rapp Py-Daniel, 2005; Wosiacki et al., 2011), included the form reported herein.

In this study we describe a third species that belongs to the $T$. hasemani group. The new species is provisionally allocated in the genus Trichomycterus until its proper taxonomic assignment is established.

\section{Material and Methods}

All measurements are taken point-to-point to the nearest $0.1 \mathrm{~mm}$ with digital calipers under stereomicroscope with incident light, preferably on the left side. Measurements follow Tchernavin (1944) except for the following: caudal peduncle

\footnotetext{
${ }^{1}$ Museu Paraense Emílio Goeldi, Setor de Ictiologia, Av. Magalhães Barata, 376, CP 399, 66040-170 Belém, PA, Brazil. guilhermedutr@yahoo.com.br, wolmar@museu-goeldi.br

2Museu de Zoologia da Universidade de São Paulo, Av. Nazaré, 481, CP 42694, 04299-970 São Paulo, SP, Brazil. pinna@ib.usp.br
} 
length (from the base of the last anal ray to the base of the median caudal rays; de Pinna, 1992); caudal peduncle depth (vertically through the middle of caudal peduncle length); body depth (vertically through the middle of SL); and eye diameter (horizontally from the anterior margin to the posterior margin of orbit). In the description, the frequency of each finray count is given in parentheses after each count. An asterisk indicates counts for the holotype.

Specimens are cleared and counterstained according to Taylor \& van Dyke (1985). Vertebral counts include only free vertebrae, with the compound caudal centrum (PU1+U1) counted as one. Vertebral counts of Trichomycterus anhanga were obtained from cleared and stained (c\&s) specimens and digital radiographs. Nomenclature for the latero-sensory system follows Arratia \& Huaquin (1995). Institutional abbreviations follow Ferraris (2007) with addition of following institutions: Laboratório de Biologia de Peixes, Universidade Estadual “Júlio de Mesquita Filho”, Botucatu, Brazil (LBP), and Laboratório de Ictiologia de Ribeirão Preto, Ribeirão Preto, Brazil (LIRP). Observations of the holotype of T. johnsoni were obtained from photographs and $\mathrm{X}$-ray images.

\section{Trichomycterus anhanga, new species Figs. 1, 2a, 3, 4}

Holotype. INPA 25125, 10.0 mm SL, Brazil, Amazonas, Novo Aripuanã, igarapé Extrema, tributary of rio Aripuanã, rio Madeira drainage, 0507’14.0”'S 60²2’46.9”W, 29 Apr 2005, L. Rapp PyDaniel, O. M. Ribeiro, L. M. Sousa \& A. Galuch.

Paratypes (all from Brazil). INPA 36117, 3, 9.8-10.6 mm SL, same data as holotype. MZUSP 108822, 2+1 c\&s, 9.7-10.2 mm SL, same data as holotype. INPA 31402, 1, 10.5 mm SL, Amazonas, Novo Aripuanã, igarapé Palhalzinho, tributary of rio Aripuanã, rio Madeira drainage, 0559’32.0”S 60¹2’35.0”W, 06 Sep 2007, L. R. Py-Daniel, M. S. Rocha \& R. R. de Oliveira. MPEG 6973, 1, 9.9 mm SL, Pará, Juruti, igarapé Juruti Grande, tributary of rio Amazonas, 02³4'39.0”S 56²3'59.9”W, 12 Sep 2002, W. B. Wosiacki \& A. Bezerra. MPEG 14356, 1 c\&s, 13.1 mm SL, Pará, Juruti, igarapé Mutum, tributary of rio Aruã, tributary of rio Branco, rio Arapiuns basin, rio Tapajós drainage, $02^{\circ} 36^{\prime} 42.0^{\prime}$ 'S 56 11 ’36” $\mathrm{W}$, 27 Nov 2007, A. Hercos.

Diagnosis. Trichomycterus anhanga differs from all other congeners by its reduced latero-sensory canal system, which is restricted to a short section between LL1 and LL2, on the pterotic, and entirely absent on the rest of body and cranium. It also differs from all other species currently in Trichomycterus except $T$. hasemani and $T$. johnsoni by the single hypertrophied cranial fontanel, which occupies nearly the entire skull roof ( $v s$. fontanel restricted to one or more narrow spaces along the dorsal midline of skull).

Trichomycterus anhanga differs further from T. hasemani and $T$. johnsoni by the presence of three $(i, 2)$ pectoral-fin rays (vs. i,3-5 rays); the absence of pelvic fins and girdle (vs. presence); the reduced oral dentition, with only two teeth each on premaxilla and dentary (vs. teeth numerous in both upper and lower jaws); the reduced pharyngeal dentition, with only a single tooth in the lower pharyngeal plate and none in the upper (vs. pharyngeal dentition well developed); the presence of five to seven odontodes in the interopercle (vs. 9-10 in $T$. hasemani and 9-12 in T. johnsoni), the absence of procurrent rays anterior to dorsal and anal fins ( $v s$. one vestigial ray anterior to the main ray series in each fin), the lack of a lateral series of dark spots (vs. presence); the presence of a small dark spot on the ventral surface of the lower lip (vs. absence); the narrow comma-shaped palatine, lacking a posterior process (vs. palatine broad, with large posterior process) (Fig. 2); the lack of a parasphenoid (vs. parasphenoid present); the presence of a single pair of pleural ribs ( $v s$. two or three ), the insertion of the first dorsal-fin pterygiophore anterior to the neural spine of the $16^{\text {th }}$ vertebra (vs. $17^{\text {th }}$ or $18^{\text {th }}$ vertebra in $T$. johnsoni, and $18^{\text {th }}$ to $20^{\text {th }}$ in $T$. hasemani). It can be further distinguished from $T$. hasemani by the insertion of the first anal-fin pterygiophore anterior to the hemal spine of $16^{\text {th }}$ vertebra (vs. anterior to hemal spine of $19^{\text {th }}-20^{\text {th }}$ vertebra); and from T. johnsoni by the absence of irregular longitudinal dark lines on the sides of the body (vs. presence), the absence of a dark midventral line (vs. presence), and the smaller interorbital distance (17.8-23.2\% SL vs. 25.5$37.0 \% \mathrm{SL})$.

Description. Morphometric data given in Table 1. Body elongate, approximately cylindrical near head, progressively more compressed posteriorly to strongly compressed caudal peduncle. Dorsal profile gently convex from tip of snout to posterior margin of head and straight from this point to end of caudal peduncle. Dorsal-fin base in recess on dorsal profile of body. Ventral profile straight from snout tip to pectoral-fin origin, gently convex from that point to anus, then straight to end of caudal peduncle. Anal opening on vertical line through origin of dorsal fin.

Head depressed, its greatest width across bases of interopercular odontodes; snout round in dorsal view; lateral surface of head with well-developed muscle protruding from posterior margin of eye to opercular patch of odontodes. Eye small and circular, with well-defined margin, located on anterior half of HL, dorsally oriented.

Anterior nostril round, its diameter equal to eye lens, surrounded by short tube of integument continuous posterolaterally with nasal barbel. Posterior nostril occluded anteriorly by fleshy integument shaped like a half-shell, positioned closer to eye than to anterior nostril. Posterior nostril slightly displaced medially relative to line between anterior nostril and eye.

Mouth subterminal, with corners slightly posterolaterally oriented. Upper lip extending slightly further anteriorly than lower one, its anterior margin gently rounded in ventral view, continuous laterally with bases of maxillary and rictal barbels. Lower lip thinner than upper one, its anterior margin gently rounded in ventral view. Jaw dentition reduced, with two conical feeble teeth on each premaxilla and each dentary (Fig. 3).

Barbels elongate, wider at base, narrowing gradually distally, ending in sharp filament. Origin of nasal barbel on 

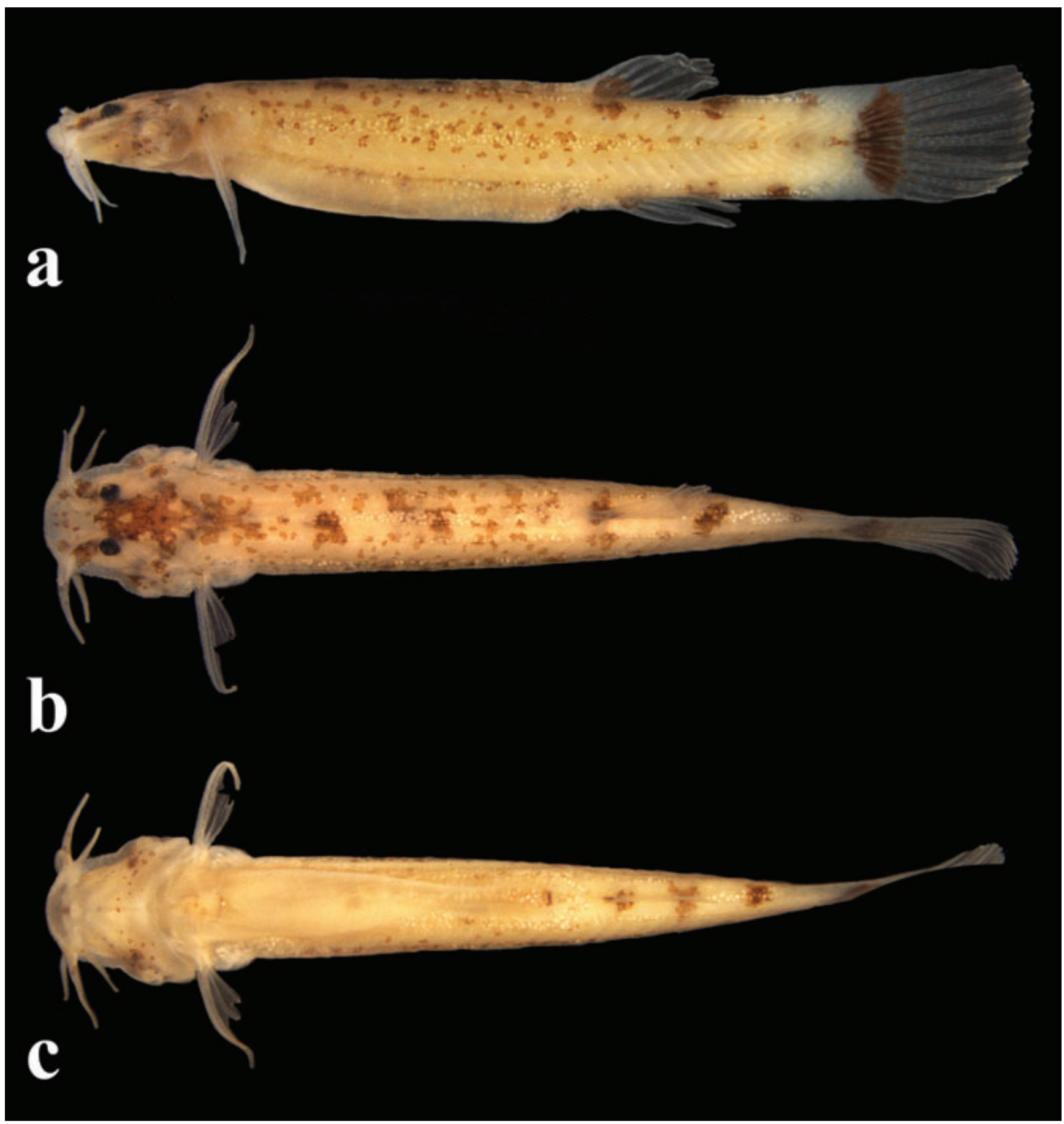

Fig. 1. Trichomycterus anhanga, holotype, INPA 25125, $10.0 \mathrm{~mm}$ SL. Brazil, Amazonas, igarapé Extrema, tributary of rio Aripuanã, rio Madeira drainage. a) lateral view; b) dorsal view; c) ventral view.

posterolateral portion of anterior nostril, reaching posterior margin of eye or slightly beyond that. Maxillary barbel variably reaching to point between base and posterior limit of interopercular patch of odontodes. Rictal barbel variably reaching to point between base and middle of interopercular patch of odontodes; its base lacking fleshy lobe.

Interopercle with five to seven (six*) odontodes. Interopercular patch with odontodes arranged in two main series. Opercle with six to 10 (seven*) odontodes (Fig. 4). Odontodes on anterior series straight and those on posterior series slightly longer and curved medially. Opercle with small odontodes anterior to first series. Gill membrane united to isthmus only at anteriormost portion. Gill opening wide. Branchiostegal rays, four* or five.

Pectoral fin i,2, with first ray prolonged as filament and branched rays approximately one third of length of first ray. 


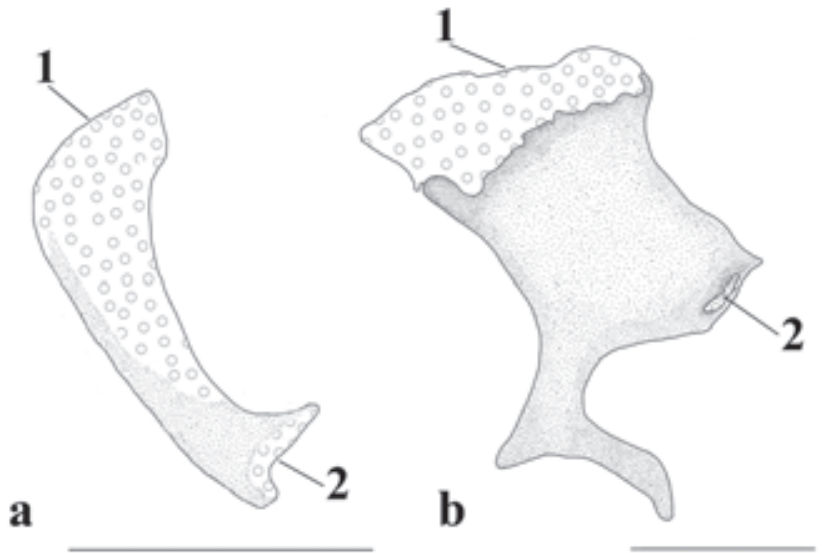

Fig. 2. Palatine in Trichomycterus, dorsal view. a) T. anhanga, left side, INPA 36117, paratype; b) T. hasemani, inverted of right side, MPEG 4968. Scale bars $=0.1 \mathrm{~mm} .1=$ anterior articular facets; 2 = posterior articular facets.

Dorsal fin ii,5(5), iii,3(1), or iii,4*(2), its distal margin rounded; unbranched rays gradually increasing in size, last unbranched ray and first branched ray larger than others, branched rays gradually decreasing in size. Anal fin ii,4, its distal margin gently convex; first unbranched ray two-thirds of length of second ray; second unbranched ray and first branched ray longer than others; branched rays slightly decreasing in size, with their origin at vertical through second or third dorsal-fin ray. Caudal fin truncate, i,8,i(1), i,8,ii(1), ii,7,ii(2) or iii,7,ii*(5). Procurrent caudal-fin rays six or seven* dorsally (eight visible in c\&s), and six* or seven ventrally, visible in alcoholic specimens. Pelvic fin and girdle absent.

Lateral line with two pores dorsal to pectoral-fin insertion, LL1 and LL2. Cephalic portion of latero-sensory canal system (supraorbital, infraorbital and preorbital) absent. Vertebrae 29(1), 31(3), or 32(4). One pair of pleural ribs. Dorsal fin with seven or eight pterygiophores, first one anterior to neural spine of $16^{\text {th }}$ or $17^{\text {th }}$ free vertebrae. Anal fin with six pterygiophores, first one anterior to hemal spine of $16^{\text {th }}$ vertebra.

Color in ethanol. Ground color cream. Flank, dorsum, and posteroventral region with tiny light brown spots, irregular in shape. Dorsum with series of four to eight transverse dark brown spots; when eight, first to fifth ones anterior to dorsal fin insertion, sixth over dorsal-fin origin, seventh on vertical line through posterior margin of dorsal fin and eighth on posterior portion of caudal peduncle. Series of three to five dark brown transverse spots on ventral surface of body; first one immediately anterior to anus, second at origin of anal-fin base, third immediately posterior to anal-fin base, fourth approximately in middle of caudal peduncle, and fifth near insertion of first ventral caudal-fin procurrent rays.

Ground color of head cream. Snout with spot extending from base of maxillary barbel to anterior margin of eye. Region

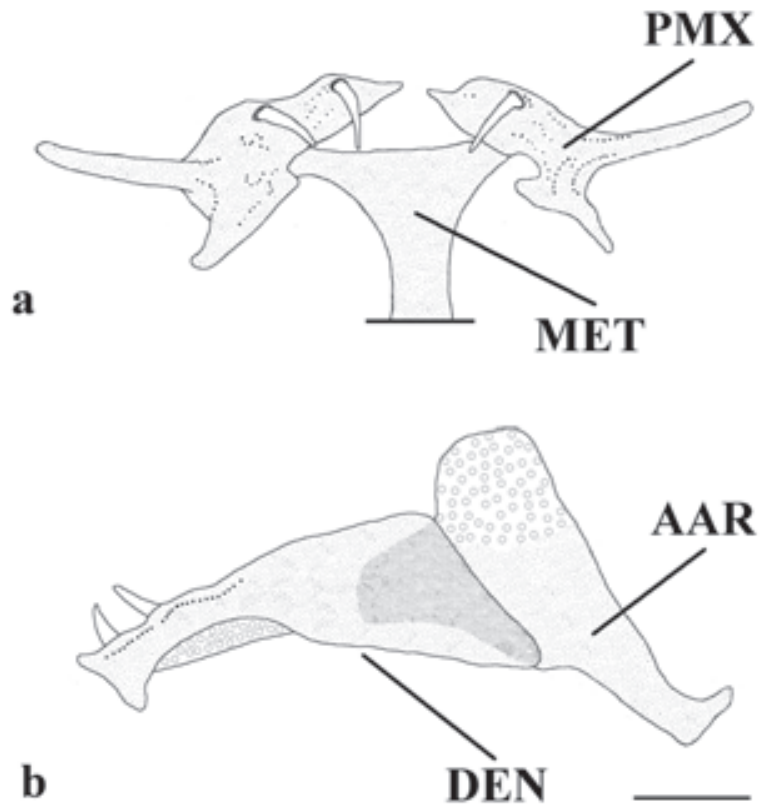

Fig. 3. Jaws of Trichomycterus anhanga, MZUSP 108822. Scale bars $=0.1 \mathrm{~mm}$. a) upper jaw in ventral view; b) lower jaw in ventrolateral view, left side. $\mathrm{PMX}=$ premaxilar, $\mathrm{MET}=$ mesethmoid, DEN = dentary; AAR = anguloarticular.

of neurocranium with light brown spot extending lateroventrally to interopercular patch of odontodes, sometimes merging with first dorsal spot. Ventral surface of head with few light brown chromatophores concentrated between interopercular odontodes. Ventral surface of lower lip with conspicuous dark spot at symphysis. Opercular and interopercular patches of odontodes with few chromatophores more concentrated at odontode bases. Nasal, maxillary and rictal barbels with small brown spots on dorsal surface, more concentrated basally.

Pectoral fin hyaline. Bases of dorsal and anal fins with light brown spot on insertion of first three rays, individuals without spots sometimes with few brown chromatophores on dorsal and anal fins. Caudal fin with dark brown vertical bar at base, darker across central rays, gradually lighter toward dorsal and ventral ends. Middle part of fin with dark brown chromatophores, more concentrated near spot at base; edge hyaline.

Distribution. Known from igarapé da Extrema and igarapé Palhalzinho, tributaries to the rio Aripuanã, itself a tributary to the rio Madeira; igarapé Juruti Grande, tributary to the right margin of the rio Amazonas; and igarapé Mutum, a tributary of the rio Aruã, a tributary of rio Branco, itself tributary of the rio Arapiuns, tributary of the rio Tapajós basin (Fig. 5).

Etymology. The specific name anhanga is a reference to the Amazonian Anhangá legend, a spirit that lives in the woods, 


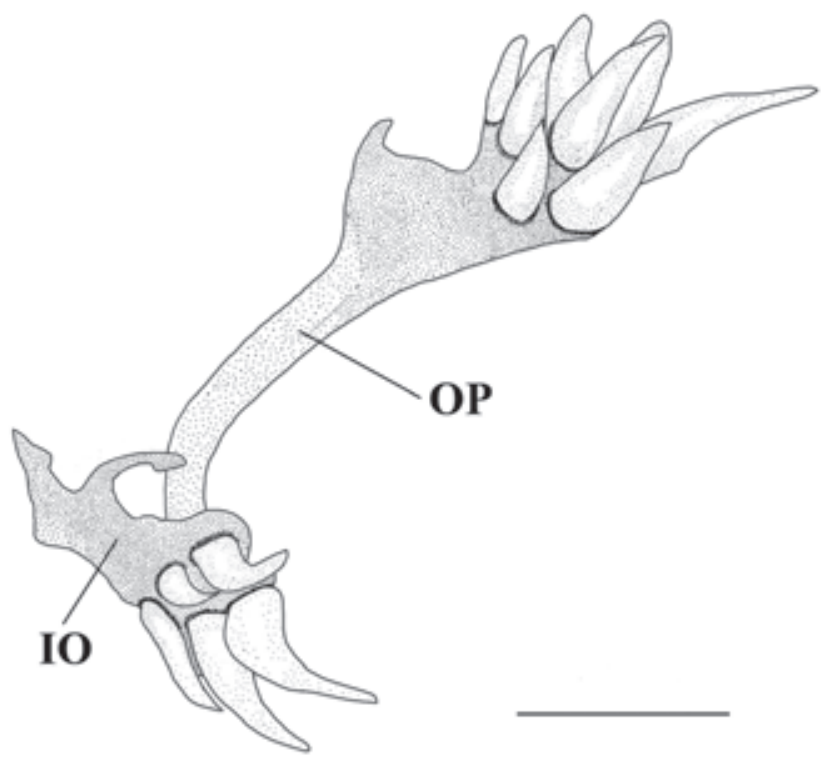

Fig. 4. Opercle and Interopercle of Trichomycterus anhanga, lateral view, left side, INPA 36117, paratype. OP = opercle; IO $=$ interopercle. Scale bar $=0.1 \mathrm{~mm}$.

protector of animals. Its presence can be detected by a whistle and thereafter, the animal that was being hunted disappears. Anhangá is thus regarded as a protector of forest life. A noun in apposition.

\section{Discussion}

Trichomycterus anhanga belongs to the clade herein referred to as the $T$. hasemani group. The first proposal that the group T. hasemani was monophyletic and not closely related to the subfamily Trichomycterinae was made by de Pinna (1989). According to that publication, T. hasemani and T. johnsoni formed a monophyletic group, itself more closely related to Tridentinae than to members of the Trichomycterinae. In a subsequent analysis (Wosiacki, 2002), the $T$. hasemani group was confirmed as monophyletic on the basis of several additional characters: 1- a wide fontanel that occupies most of the skull roof and is delimited by the frontal and supraoccipital; 2- the absence of the anterior portion of the infraorbital canal (pores i1 and i3); 3- the first pectoral-fin ray much longer than the others; 4- the absence of branchiostegal rays on the posterior ceratohyal; and 5- a large posterior process of the palatine, partly forked and expanded distally.

Trichomycterus anhanga shares the first four of those characters. The condition of its palatine, however, invites further explanation on the last character. Both T. hasemani and $T$. johnsoni share a large and conspicuous posterior process on the palatine, partly bifurcated distally, which is entirely absent in T. anhanga. While this is clearly a derived condition shared by T. hasemani and T. johnsoni only, other
Table 1. Morphometric data for holotype and paratypes of Trichomycterus anhanga ( $\mathrm{n}=9$ including holotype).

\begin{tabular}{|c|c|c|c|c|c|}
\hline & Holotype & Min. & Max. & Mean & SD \\
\hline Standard length (SL, mm) & 10.0 & 9.7 & 13.1 & - & - \\
\hline \multicolumn{6}{|c|}{ Percentage of SL } \\
\hline Total length & 120.7 & 113.9 & 126.3 & 119.3 & 3.5 \\
\hline Body depth & 16.9 & 11.6 & 16.9 & 14.0 & 1.7 \\
\hline Peduncle length & 22.3 & 21.6 & 24.9 & 23.5 & 1.1 \\
\hline Peduncle depth & 15.2 & 10.7 & 15.2 & 12.5 & 1.7 \\
\hline Predorsal length & 66.2 & 65.5 & 69.4 & 67.8 & 1.5 \\
\hline Preanal length & 68.2 & 63.5 & 71.4 & 67.4 & 2.3 \\
\hline Dorsal-fin base length & 8.0 & 7.5 & 10.1 & 8.6 & 0.8 \\
\hline Anal-fin base length & 7.8 & 5.5 & 9.2 & 7.7 & 1.0 \\
\hline Head length (HL) & 18.4 & 17.2 & 20.2 & 18.4 & 1.0 \\
\hline \multicolumn{6}{|c|}{ Percentage of HL } \\
\hline Head width & 93.5 & 80.6 & 96.3 & 89.1 & 5.5 \\
\hline Head depth & 33.0 & 33.0 & 50.3 & 40.2 & 5.3 \\
\hline Interorbital & 19.5 & 17.8 & 23.2 & 20.6 & 1.7 \\
\hline Snout length & 31.9 & 23.0 & 37.2 & 31.4 & 4.6 \\
\hline Nasal babel length & 30.8 & 26.5 & 39.8 & 32.1 & 4.6 \\
\hline Maxillary babel length & 41.6 & 37.0 & 55.0 & 45.9 & 6.0 \\
\hline Rictal barbel length & 34.1 & 32.2 & 53.9 & 39.8 & 7.4 \\
\hline Mouth width & 31.9 & 22.5 & 38.8 & 28.6 & 4.9 \\
\hline Eye diameter & 15.1 & 13.6 & 19.0 & 15.9 & 1.7 \\
\hline
\end{tabular}

aspects of the palatine morphology are shared also by $T$. anhanga. In all three species, the main axis of the palatine is deflected mesially, so that its anterior and posterior articular facets are oriented nearly at a right angle to each other. Such similarity is partly obscured by modifications of other sorts in the palatine of the different taxa. In both $T$. hasemani and $T$. johnsoni, the palatine is broad and prolonged posteriorly by the large process mentioned above. In T. anhanga, contrastingly, the palatine is narrow, roughly comma-shaped, and practically restricted to its main axis. If such subsidiary differences are disregarded, the three species clearly share a similar medial bending of the main axis of the palatine. Therefore, the three species of the $T$. hasemani group share a medially-bent palatine where the articular facet for the maxilla is positioned at a right angle relative to the articular facet for the neurocranium. Within that group, $T$. hasemani and $T$. johnsoni share an expanded, partly bifurcated posterior process.

In a broader phylogenetic analysis involving numerous representatives of Trichomycteridae, Wosiacki (2002) proposed the T. hasemani group as sister group to the clade composed of the subfamilies Tridentinae, Stegophilinae and Vandelliinae. Characters for that hypothesis include the presence of a subdivided Meckel's cartilage, with a small isolated portion on the dorsal tip of the coronoid process; the foramen of the ramus mandibularis internus trigeminus on the ventral surface of the dentary; and the dorsal edge of the angle-joint of the coronoid process extending dorsal to the edge of the dentary. All such characters have been confirmed in T. anhanga.

The absence of the anterior portion of the infraorbital canal (corresponding to pores i1 and i3) was confirmed in all the examined material and is a valid synapomorphy for the $T$. 


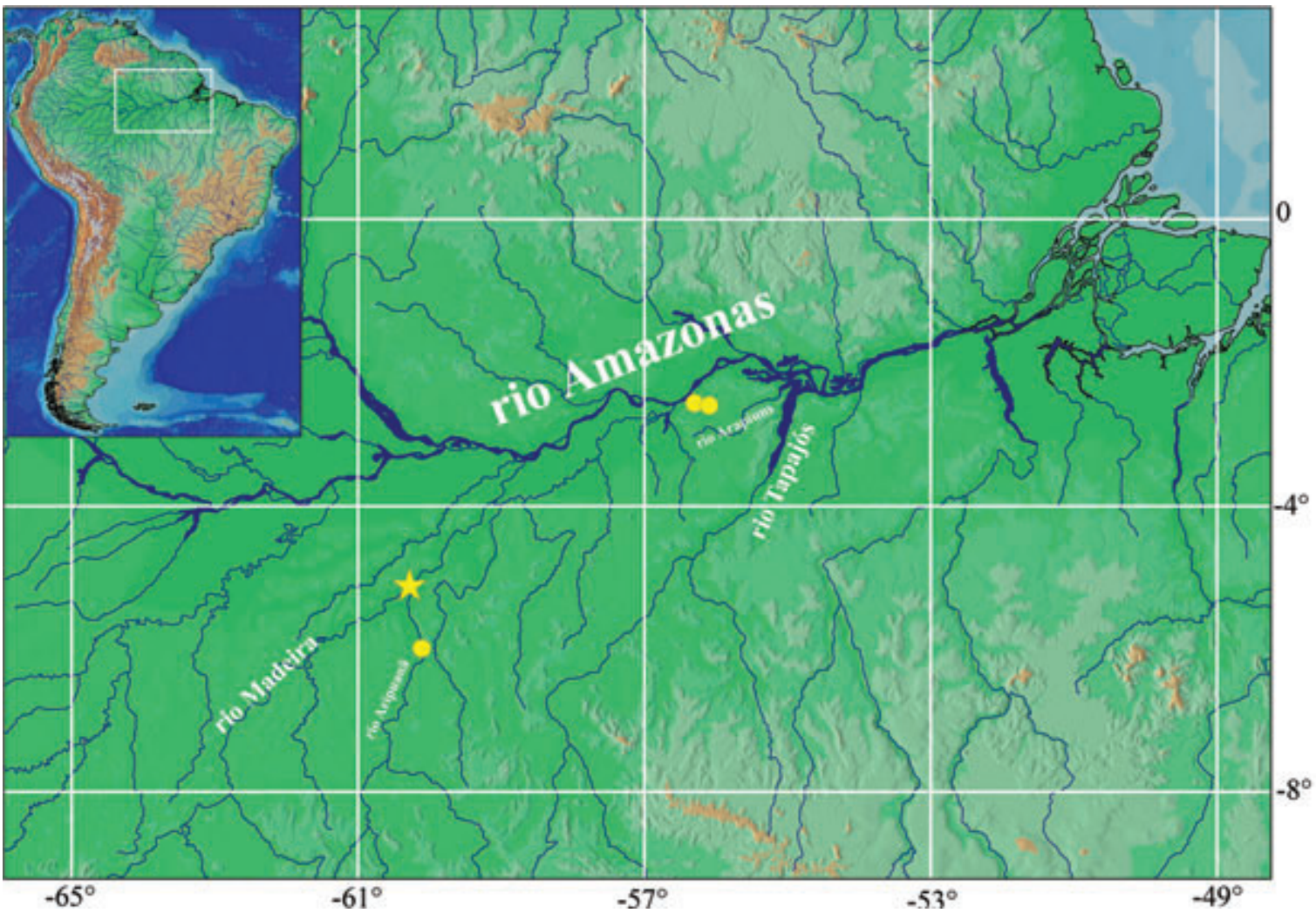

Fig. 5. Map of northern South America showing the distribution of Trichomycterus anhanga. A star indicates the type locality.

hasemani group. However, in Trichomycterus anhanga this system is further reduced to an extreme degree, with the laterosensory canal system restricted to a short canal between pores LL1 and LL2, an evidently autapomorphic trait. The reduction of the cephalic portion of the sensory canal system is considered a synapomorphy of the Glanapteryginae by de Pinna (1998). However, given the phylogenetic distance between glanapterygines and the T. hasemani group (de Pinna, 1998; Wosiacki, 2002) it is more parsimonious to interpret the reduction of the pores of the cephalic sensory system in the two clades as convergent.

Wosiacki (2002) proposed the absence of branchiostegal rays in the posterior ceratohyal as a putative synapomorphy for Trichomycterus hasemani group, which is present in $T$. anhanga. Conversely, a more comprehensive analysis of $T$. hasemani and T. johnsoni demonstrated that the proposed character is polymorphic. Thus, the definition of that character should be slightly modified to absence, or presence of one branchiostegal ray on the anterior margin of the posterior ceratohyal [T. hasemani, $0(8)$ or $1(1)$ and $T$. johnsoni, 0(1) or 1(9)].

A reduction in the number of pectoral-fin rays is considered as a synapomorphy for Glanapteryginae (de Pinna, 1998). A similar reduction in T. anhanga, is again more parsimoniously interpreted as non-homologous. The absence of pelvic fins is known for other species of Trichomycterinae, in at least three distinct genera, Trichomycterus ( $T$. catamarcensis, T. candidus and T. tropeiro), Eremophilus (E. mutisii), and Silvinichthys (S. bortayro) and these should also be interpreted as independent events.

Weitzman \& Vari (1988) recorded three miniature species in Trichomycterinae: Trichomycterus hasemani, T. johnsoni and T. santaeritae (Eigenmann). Because the phylogenetic relationships of the subfamily were not well understood at that time, the authors hypothesized that this was the result of a single miniaturization event in Trichomycterinae. De Pinna (1989), after evaluating the characters used to diagnose Trichomycterinae, suggested that $T$. santaeritae might be closer to Sarcoglanidinae and T. hasemani and T. johnsoni were related to other taxa in Trichomycteridae. The latter hypothesis was confirmed by Wosiacki (2002), where $T$. hasemani and T. johnsoni form a monophyletic group which is the sister group to Tridentinae+Stegophilinae+Vandelliine. Trichomycterus anhanga is as miniaturized as the rest of the T. hasemani group. Thus, it is more parsimonious to interpret a single miniaturization event in the Trichomycterus hasemani group and the situation in $T$. santaeritae as homoplastic.

Comparative material. Trichomycterus hasemani: FMNH 56424, holotype, 11.0 mm SL, Brazil, Pará State, Santarém. CAS 64584, paratypes, 5, $13.0 \mathrm{~mm}$ SL, same locality as holotype. MZUSP 59163, 5+1 c\&s, 12.5-13.8 mm SL, lago da Várzea, rio Negro. MZUSP 93953, 17+2 c\&s, 14.5-14.7 mm SL, igarapé Boi Boi, rio Negro. LBP 4447, 29, 14.1-15.5 mm SL, igarapé Zalata, rio Negro. LIRP 7393, 27+3 c\&s, 12.3-14.3 mm SL, igarapé Au-Au, rio Branco. LIRP 7395, 
13+3 c\&s, 12.3-14.1 mm SL, igarapé Murupu, rio Branco. LIRP 7397, 42+4 c\&s, 12.7-14.8 mm SL, igarapé Água Boa, rio Branco. MPEG 14321, 13+3 c\&s, 10.9-14.4 mm SL, rio Saracá, rio Trombetas. MZUSP 92745, 15, 12.0-14.4 mm SL, right margin of rio Tapajós. MPEG 10412, 49+5 c\&s, 11.7-14.2 mm SL, tributary of Caxiuanã bay. MPEG 4968, 102+5 c\&s, 10.9-12.7 mm SL, rio Goiapi, Marajó island. MCP 23068, 2, 12.4-13.0 mm SL, tributary of rio Acará, rio Guamá-Capim. Trichomycterus johnsoni: ANSP 53873, holotype, $16.0 \mathrm{~mm}$ SL, Brazil, Mato Grosso, Descalvados (only photos and Xray). MZUSP 95013, 30+3 c\&s, 12.6-14.9 mm SL, rio Mutum, rio Paraguai. MZUSP 96179, 21, 2 c\&s, 11.7-14.6 mm SL, flooded area, road to Mimoso, rio Paraguai. MZUSP 59367, 1+1 c\&s, $12.2 \mathrm{~mm}$ SL, rio Abobral, rio Paraguai. AI 246, 10, 14.2-16.7 mm SL, Laguna Disparo, Corrientes. Tridensimilis sp.: MPEG 18062, 1, 18.5 mm SL, igarapé da Onça, rio Urucu. Tridentopsis sp.: MZUSP 63092, 1 c\&s, $22.0 \mathrm{~mm}$ SL, Formosa, Argentina. Miuroglanis sp.: MPEG 14257, 1, 14.1mm SL, igarapé Guaraná. Paravandellia sp.: MPEG 3748, 1, 28.7 mm SL, baía do Guajará, rio Guamá.

\section{Acknowledgements}

We first thank the following individuals and institutions for access to material under their care: C. Lucena and M. Lucena (MCP), C. Oliveira (LBP), F. Bockmann (LIRP) and L. Py-Daniel (INPA). Special thanks go to M. Rocha (INPA) and K. Luckenbill (ANSP) for photos and X-rays of the holotype of Trichomycterus johnsoni; A. Colares and M. Mehanna (LBP) for help in getting study material; O. Oyakawa (MZUSP) for help in locating study material and other assistance. Nancy Lo-Man-Hung, B. Rodrigues and A. Bonaldo (MPEG) kindly assisted us with photos of the holotype of Trichomycterus anhanga. GMD thanks the Conselho Nacional de Desenvolvimento Científico e Tecnológico (CNPq) for granting the scholarship (process: 134550/2009-9), and Coordenação de Aperfeiçoamento de Pessoal de Nível Superior (CAPES) for funding the trip to Porto Alegre through the Programa Nacional de Cooperação Acadêmica (NF-PROCAD: 23038.042984/2008-30). Paratypes in the municipality of Juruti were collected during an expedition funded by Alcoa Alumínio S/A (Alcoa agreement / MPEG / Fides).

\section{Literature Cited}

Arratia, G. 1990. The South American Trichomycterinae (Teleostei: Siluriformes), a problematic group. Pp. 395-403. In: Peters, G. \& R. Hutterer (Eds.). Vertebrates in the Tropics. Museum Alexander Koenig, Bonn, 424p.

Arratia, G. \& L. Huaquin. 1995. Morphology of the lateral line system and of the skin of diplomystid and certain primitive loricarioid catfishes and systematic and ecological considerations. Bonner Zoologische Monographien, 36: 1-110.

Baskin, J. N. 1973. Structure and relationships of the Trichomycteridae. Unpublished Ph.D. Dissertation, City University of New York, New York, 389p.

Datovo, A. \& F. A. Bockmann. 2010. Dorsolateral head muscles of the catfish families Nematogenyidae and Trichomycteridae (Siluriformes: Loricarioidei): comparative anatomy and phylogenetic analysis. Neotropical Ichthyology, 8: 193-246.
Ferraris, C. J., Jr. 2007. Checklist of catfishes, recent and fossil (Osteichthyes: Siluriformes), and catalogue of siluriform primary types. Zootaxa, 1418: 1-628.

de Pinna, M. C. C. 1989. A new sarcoglandine catfish, phylogeny of its subfamily, and an appraisal of the phyletic status of the Trichomycterinae (Teleostei, Trichomycteridae). American Museum Novitates, 2950: 1-39.

de Pinna, M. C. C. 1992. Trichomycterus castroi, a new species of trichomycterid catfish from the Rio Iguaçu of Southeastern Brazil (Teleostei: Siluriformes). Ichthyological Exploration of Freshwater, 3: 89-95.

de Pinna, M. C. C. 1998. Phylogenetic relationships of neotropical siluriformes (Teleostei: Ostariophysi): historical overview and synthesis of hypotheses. Pp. 279-330. In: Malabarba, L. R., R. E. Reis, R. P. Vari, Z. M. Lucena \& C. A. S. Lucena (Eds.). Phylogeny and Classification of Neotropical Fishes. Porto Alegre, Edipucrs, 603p.

de Pinna, M. C. C. \& W. B. Wosiacki. 2003. Family Trichomycteridae (Pencil or parasitic catfishes). Pp. 270-290. In: Reis, R. E., S. O. Kullander, C. J. Ferraris Jr. (Org.). Checklist of the freshwater fishes of South and Central America. Porto Alegre, Edipucrs, 729p.

Sousa, L. M. \& L. H. Rapp Py-Daniel. 2005. Description of two new species of Physopyxis and redescription of P. lyra (Siluriformes: Doradidae). Neotropical Ichthyology, 3: 625-636.

Taylor, W. R. \& G. C. van Dyke. 1985. Revised procedures for staining and clearing small fishes and other vertebrates for bone and cartilage study. Cybium, 9: 107-119.

Tchernavin, V. 1944. A revision of some Trichomycterinae based on material preserved in the British Museum (Natural History). Proceedings of the Zoological Society of London, 114: 234-275.

Weitzman, S. H. \& R. P. Vari. 1988. Miniaturization in South American freshwater fishes: an overview and discussion. Proceedings of the Biological Society of Washington, 101:444-465.

Wosiacki, W. B. 2002. Estudo das relações filogenéticas de Trichomycterinae (Teleostei, Siluriformes, Trichomycteridae) com uma proposta de classificação. Unpublished Ph.D. Dissertation, Universidade de São Paulo, São Paulo, 324p.

Wosiacki, W. B., D. P. Coutinho \& L. F. A. Montag. 2011. Description of a new species of sand-dwelling catfish of the genus Stenolicmus (Siluriformes; Trichomycteridae). Zootaxa: 2752: 62-68.
Submitted May 3, 2011

Accepted April 5, 2012 Published June 29, 2012 